\title{
VEISUUN EHDOT: VIRSITEKSTIN JA SÄVELMÄN KESKINÄISESTÄ RIIPPUVUUDESTA HERÄNNÄISVEISUUSSA
}

Laulun tutkimuksessa on tärkeää ottaa huomioon, että lauluun sisältyy tavallisesti sekä melodia että teksti. Tätä mielipidettä tukevat monet etnomusikologit. George W. Boswell kirjoittaa: "... poetry and music in a song are two sides of the same coin - almost miraculously well wedded together" (Boswell 1978, 80). R.H. Robins ja Norma McLeod kirjoittavat vieläkin voimakkammin, että "... words and music are not separate for the singer." Tällä he tarkoittavat kirjoittamattomien kansojen lauluja ja tekevät selvän eron länsimaiseen taidemusiikkiin. (Robins, McLeod 1956, 592)

Nykypäivän suomalaisista tutkijoista Erkki Ala-Könni, Päivikki Suojanen ja Jukka Louhivuori ovat merkittävästi käsitelleet kansankoraaleja tutkimuksissaan. Niissä virsiä kuitenkin lähestytään pelkästään melodian kannalta ja vertaillaan eri veisaajia tai keskitytään tiettyyn alueelliseen veisuuperinteeseen. Esimerkiksi Jukka Louhivuori, joka on tutkinut veisuumelodioiden muuntelua väitöskirjassaan (1988), on kiinnittänyt huomiota nimenomaan rytmisiin ja melodisiin eroihin eri veisuukertojen välillä mutta jättänyt tietoisesti huomioimatta tekstin mahdollisen vaikutuksen edellä mainittuihin eroihin.

Olenkin omassa Sibelius-Akatemian lopputyössäni tutkinut herännäisveisuuta ja siinä nimenomaan melodisten ja rytmisten seikkojen yhteyttä 
virren tekstiin (Järvinen 1990). Sen perusteella veisuuseen kuuluvia tekijöitä ovat mielestäni veisuun temporaalisuus eli sävelten sijoittaminen aikaan, erilaisten tavujen vaikutus veisaamiseen, vanhan virsikirjan tekstin käsittelytapa eli tekstin ja melodian yhdistäminen sekä muuntelu veisuussa. Lähtökohtana on oletus tekstin vaikutuksesta lopulliseen sävelmään, esimerkiksi rytmivariaatioihin. Pidän myös mahdollisena, että melodia vaikuttaa tekstin käsittelyyn. Tärkeää on myös erottaa tapaukset, joissa teksti tai melodia eivät ole vaikuttavana tekijänä, vaan kyse on pelkästään veisaajan persoonallisesta tavasta veisata. Kansanlauluun oleellisesti liittyvät tekijät saadaan selville vain, kun pidetään laulun tekstiä ja melodiaa keskenään saman arvoisina tekijöinä. Lisäksi on myös pidettävä mielessä, että näillä tekijöillä voi olla keskinäinen vuorovaikutussuhde.

Seuraavassa esittelen lähinnä erään herännäisveisaajan tapaa yhdistää ns. vanhan virsikirjan virren tekstiä ja melodiaa. Tässä kirjan tekstin mitan epäsäännöllisyys aiheuttaa sen, että sanojen sijoittaminen melodiaan ei ole yhtä yksiselitteistä, kuin se on useimmissa nykyvirsissä. Siksi tarkastelun pääpaino on virsitekstin ja veisatun sävelmän keskinäisessä riippuvuudessa. Luon myös lyhyen katsauksen siihen, miten esimerkkiveisaaja veisaa ns. umpi- ja avotavuja ja miten hän muuntelee virren rytmiä ja melodiaa. Lähtökohtana on tässäkin oletus, että teksti vaikuttaa soivaan materiaaliin tai soiva materiaali tekstiin.

\section{Vanha virsikirja}

Suomalainen virsikirja vuodelta 1701 , ns. vanha virsikirja, oli ensimmäinen virallinen virsikirja Suomessa. Se toimitettiin Ruotsin kuninkaan käskystä (Voipio 1955, 16). Virsiä kirjassa on 413, sama määrä kuin vastaavan ajan ruotsalaisessa virsikirjassa (Ibid., 65). Kirjassa on suomalaisten virsien lisäksi ruotsalaisia, saksalaisia, tanskalaisia, ranskalaisia ja latinalaisia virsiä käännöksinä tai mukaelmina (Kurvinen IV, 291, 131). Nimitys "vanha virsikirja" otettiin käyttöön vuoden 1886 jälkeen erottamaan kirja vuonna 1886 hyväksytystä virsikirjasta (Kurvinen, 1941, 137). Tähän vuoteen päättyi vanhan virsikirjan käyttö Suomen evankelis-luterilaisessa kirkossa. Monet herätysliikkeet, $\mathrm{mm}$. herännäisyys ja erityisesti rukoilevaiset, jatkoivat kuitenkin kirjan käyttöä seuraveisuussaan (Ibid., 277). Vanhimmissa virsissä on paljon ns. liikatavuja. Voipion $(1948,21)$ mukaan "äkkinäinen laulaja joutuu tässä vähän väliä ymmälle, mille nuotille kukin tavu on sijoitettava".

Myös ns. katkaistut sanat ovat tyypillisiä näille virsille länsisuomalai- 
sen murteen mukaisesti (Kurvinen 1941, 146-147). Useimmiten virsistä on poistettu vain sanojen viimeinen tavu tai kirjain. Sanojen katkomiselle Onni Kurvinen antaa murteen lisäksi toisenkin selityksen: "Sanoja katkomalla saatiin säkeiden alkuun helposti yksitavuisia sanoja, ja kolmitavuisista sanoista saatiin kaksitavuisia, jotka paremmin soveltuivat sekä jambiseen että trokeiseen poljentoon." (Ibid., 144).

\section{Aineisto}

Valitsin Kerttu Hannulan (os. Kontio,s.1914, Ylivieska, Raudaskylä) vuonna 1986 veisaamista viidestäkymmenestäyhdestä (51) vanhan virsikirjan virrestä kahdeksan virttä. Pyysin keväällä 1989 häntä veisaamaan ne uudelleen useampisäkeistöisinä kuin edellisellä kerralla. Hän hyräili virren melodian ennen varsinaista tekstin veisaamista, jotta tekstin mahdollinen vaikutus veisuutapaan minimoituisi. Pyysin häntä valitsemaan jonkin virren, jonka hän haluaisi opettaa minulle. Samoin pyysin häntä suunnittelemaan sopimamme, hänelle vieraan säkeistön sijoittamisen tuttuun melodiaan. Itse opettelin kaksi virttä, toisen mahdollisimman tarkasti Hannulan mukaan ja toisesta lähinnä vain melodian, jotta joutuisin miettimään vaihtoehtoja tekstin sijoittamisessa. Toisinaan kävi niin, etten osannut sijoittaa sanoja melodiaan, jolloin Hannula välittömästi korjasi tilanteen. Arvelin kaiken tämän omalta osaltaan tuovan esille hänen käsitteistönsä ja tietoisuuden sanojen ja melodian yhdistämisestä. Lainasin Hannulalta hänen käyttämänsä virsikirjan vuodelta 1923 ja kopioin sen, jotta analyysin tulos olisi senkin puolesta totuudenmukaisempi. Eri painoksissa saattaa nimittäin olla pieniä eroja tekstissä.

Olen tässä tutkimuksessani käyttänyt hyvin pientä osaa materiaalistani. Koko analyysi perustuu varsinaisesti yhteen virteen, josta on versio sekä vuodelta 1986 että 1989. Kyseessä on vanhan virsikirjan virsi nro 262, "O Jeesu elämän Herra". Olen käyttänyt analyysissä kaikkia kahteen kertaan nauhoittamiani virsiä lähinnä todentamaan esimerkkivirren analyysin antamaa tulosta.

\section{Tutkittava virsi}

Virsi 262, "O Jeesu elämän Herra", kuuluu Väinö Malmivaaran mukaan eniten veisattujen joukkoon Pohjanmaan ja Savon heränneiden keskuudessa (lainannut Kurvinen 1941, 278). Erkki Ala-Könni on tarkkaillut keruu- 
matkoillaan virsien valintaa veisuutilanteissa. Nurmolaisten keskuudessa virsi 262 kuuluu enimmin käytettyjen joukkoon (Ala-Könni 1974, 171). Omissa kokoelmissani minulla on tämä virsi neljän veisaajan veisaamana.

"O Jeesu elämän Herra" on Maskun kirkkoherran, Hemminki Henrikinpojan eli Hemminki Maskulaisen (n.1550-1619) suomentama (Kurvinen 1941, 26; vuoden 1938 virsikirjan sisällysluettelon tieto). Alunperin teksti on tanskalaisen virsirunoilijan, Malmön kirkkoherran, Hans Christensson Sthenin (k.1610) sepittämä, "O Jesu Liffsens Herre". Virsi julkaistiin ns. Maskun Hemmingin virsikirjassa, joka ilmestyi todennäköisesti keväällä 1614 (Ibid., 27). Onni Kurvinen (1941, 36-38) kirjoittaa Hemmingistä runoilijana:

Alkusointu ja säekerto ovat tavallisia kaunistuskeinoja Hemmingin virsissä, ja ilmeisesti ne ovat vaikutteita kansanrunoudesta, joka niinä aikoina näyttää olleen yleisesti tunnettuja. Metrilliseltä kannalta arvostellen havaitsemme Hemmingin virsissä paljon puutteellisuuksia. 1600-luvun alkupuolella Ruotsin virsirunoilijat suosivat "tavuja laskevaa" runoilutapaa, mutta Hemminki ei ole sitä harrastanut. Yleensä hänen virsissään on runsaasti liikatavuja, joten poljento on epäsäännöllistä.

Vuoden 1886 virsikirjassa virsi on nro 231, "Jesus, elämän Herra" ja vuoden 1938 virsikirjassa nro 284, "Oi Jeesus elämäni". Nykyisessä vuoden 1986 virsikirjassa virttä ei ole, joten virren elinaika Suomen virsikirjoissa oli noin 370 vuotta (1614-1986). Virren melodia on hieman lyhempänä myös Siionin virret -kokoelmassa virsi nro 191, "Sävyisä paimenemme".

Sekä Siionin virsien että Suomen evankelis-luterilaisen virsikirjan nuottipainoksessa melodiasta sanotaan, että se on "suomalainen". Virren melodia noudattaa kuitenkin ns. saksalaisen kansanlaulun rakennetta: "Ensin on kaksi rinnakkaista säeparia (Stollen), jotka lauletaan samalla sävelmällä, ja sitten 'loppulaulu' (Abgesang), jonka viimeinen säe vielä kerran toistaa osan alkuparin sävelmästä." (Voipio 1948, 24). Virressä 262 on kahdeksan säettä. Tässä työssä säe ymmärretään yhtäjaksoisena veisuuna, jota hengitykset ympäröivät. Olen merkinnyt säkeet virren nuotinnokseen seuraavasti: a $\quad b \quad a^{1} \quad b^{1} \quad c \quad d \quad d^{1}$ e. Näistä melodisesti ${\underline{a}=a^{1}}^{1} \underline{b=b^{1}}, \underline{d}$ $\equiv \mathrm{d}^{1}$ ja $\underline{\mathrm{e}=\mathrm{b}}$, joten virren säerakenne voitaisiin kirjoittaa myös: $\underline{\mathrm{a} \quad \mathrm{b}} \underline{\mathrm{a} b}$ $\underline{c} \mathrm{~d} d \underline{b}$. Edellä mainittu saksalaisen kansanlaulun rakenne ilmenee selkeästi: säepari $a b$ kerrataan ja lopuksi on säkeiden $c d d$ jälkeen vielä säe $b$.

Kerttu Hannula veisasi vuonna 1986 ensimmäisen säkeistön kahteen kertaan, sekä kolmannen ja neljännen säkeistön. Vuonna 1989 hän veisasi virren ensin hyräillen ja sitten kaikki neljä säkeistöä (ks. liite: Vanhan 
virsikirjan virsi 262, Kerttu Hannula (s.1914) 1.1), 1., 3. ja 4. 12.8.1986; 0-4. 25.3.1989)

\section{Nuotinnoksen teon periaatteet}

Kerttu Hannulan veisuu on säestyksetöntä yksinlaulua. Hän voi siten vapaasti valita veisuukorkeuden, nopeuden sekä yksittäisten sävelten kestot ja sävelkorkeudet. Veisuusta on mahdollista tulla suhteellisen vapaarytmistä ja sen nuotintaminen on vaikea tehdä yksiselitteisesti. Veisuuta, jonka sisäinen tempo vaihtelee ja jossa käytetään puolta sävelaskelta pienempiä intervalleja, ei pysty täydellisesti kuvaamaan länsimaisen taidemusiikin tarpeisiin kehitetyllä notaatiolla. Jotta nuotinnos olisi mahdollisimman selkeä lukea, kirjoitin sen neljäsosanuotin mittaisilla iskualoilla eteneväksi, kuten useissa virsikirjoissakin on tehty. Käytin erilaisia lisämerkintöjä kuvaamaan veisuuta tarkemmin. Merkitsin esimerkiksi hänen käyttämänsä sanatäydennykset, eli kohdat, joissa hän veisaa virsikirjassa heittomerkillä katkaistuiksi merkityt tavut kokonaisina ("mi-nul-le") ja täydentämättä jättämisensä ("viel’") sekä sanamuutokset ("tääl- tää").

Rytmi $\overbrace{\frac{3}{3}}$ tarkoittaa samaa kuin ta lukeminen selkiytyisi ja saisin yhteen iskualaan yhden kokonaisuuden: yksi sävel tai sävelet samaan palkkiin. Nuotin yläpuolella on merkki $\cup$, mikäli todellinen sävelen kesto on hieman lyhyempi kuin kirjoitettu nuottiarvo, ja vastaavasti $\cap$, kun todellinen kesto on hieman pitempi kuin kirjoitettu nuottiarvo. Puolta sävelaskelta pienempien intervallien käyttö on merkitty seuraavasti: $\downarrow$, kun sävel on hieman matalampi kuin sen kirjoitettu korkeus ja vastaavasti $\uparrow$, kun sävelen taso on hieman korkeampi kuin kirjoitettu taso. Merkitsin selvästi erottuvat painotukset ${ }^{\circ}$-merkillä sävelen yläpuolelle.

En merkinnyt nuotinnokseen sanojen todellista lausumista muuten kuin niiden tapausten osalta, jolloin konsonantit $\mathrm{n}$ ja 1 kuuluivat ikään kuin omina tavuinaan ("pa-1-jon").

\section{Tutkimusmetodi}

Etsin erilaisia tapoja, joilla voi saada selville joitakin säännönmukaisuuksia yleensä vanhan virsikirjan tekstin käsittelystä käytännössä. Tottumattoman on yleensä hyvin vaikea saada teksti ja melodia sopimaan yhteen luontevasti. Olen laatinut viisi väitettä tekstin ja melodian yhdistämisestä. Tes- 
taan niitä virteen 262 . Väitteet perustuvat huomioihin, joita tein jo aikaisemmin virsiä nuotintaessani. Väitteiden todenperäisyyden tarkasteluvaiheessa apuna on Taulukko 1, johon on merkitty lukumäärin virsikirjan painetut ja Kerttu Hannulan veisaamat tavumäärät sekä melodisten sävelten lukumäärät virressä 262. Väitteiden antamien tulosten perusteella etsin selityksiä sanatäydennyksille ja muutoksille. Tarkastelen myös, missä määrin Hannula pyrkii murrelmattomiin säkeisiin. Murrelma voidaan tässä selittää siten, että sanan painoton tavu sattuu melodian painolliselle osalle. Koska en ole käyttänyt tahtiviivoja nuotinnoksessa, täytyy tyytyä vain tuntumaan siitä, mikä sävel on painollinen tai painoton. Ainakin kahdeksasosanuottiparin jälkimmäinen sävel on painoton. Yksityiskohtien tarkastelun perusteella en esitä ehdottomia sääntöjä, vaan etsin sääntöjen välille hierarkiaa eli arvojärjestystä, jonka perusteella vanhan virsikirjan tekstin sijoittaminen melodiaan sanatäydennyksineen olisi helpompi tehdä 'tyylinmukaisesti'.

\section{Analyysi}

Kerttu Hannula viittasi keskusteluissamme usein siihen, että jossakin virressä oli "vaikeat sanat" (muistiinpanot), eli tekstin "kuljettaminen", sijoittaminen melodiaan, oli hänen mielestään vaikeaa. Vanhan virsikirjan tekstille on tyypillistä, että säkeiden tavumäärät eivät ole eri säkeistöissä aina vakiot. Käsittelemässäni virressä 262 ero on suurimmillaan neljä tavua (Taulukko 1, säe $\mathrm{a}^{1}$, sarake VVK 1923). Hannula lisää tavumäärää täydentämällä ns. katkaistut sanat kokonaisiksi. Sanojen täydentäminen on hänelle tietoista: "Monesti sanat täydennettiin" (10.8.1986, muist.p.).

Hän ei silti tunnu tällä pyrkivän tavumäärän tasaamiseen, kuten Taulukko 1 osoittaa, vaan kyseessä on veisuutapa. Selvitän kuinka paljon Hannula täydentää sanoja ja onko eri vuosina eroja. Lisäksi yritän selvittää täydennysten ja täydentämättä jättämisten paikat väitteiden avulla, eli pyrin saamaan käyttökelpoisen tuloksen käsittelemällä aihetta laajasti (deduktiivinen päättelymalli). "Kuljettamista" selvitän myös etsimällä melodiasta kohdat, joita ei yleensä ylitetä murrelmatavulla.

TAULUKKO 1: Painettujen ja veisattujen tavujen sekä melodisten sävelten lukumäärä säkeittäin eri säkeistöissä

Taulukko 1 on eräänlainen sisällysluettelo Kerttu Hannulan veisaamasta virrestä 262. Tiettyjä lukuja vertaamalla tiedetään suurin piirtein, miten 
veisaaja käsittelee virren tekstiä ja melodiaa eri säkeistöissä. Painettujen sanojen tavumäärää laskettaessa olen käyttänyt kopiota Hannulan käyttämästä virsikirjasta vuodelta 1923. Ensimmäinen pystysuora sarake (VVK1923) näyttääkin, kuinka monta tavua on vuoden 1923 virsikirjassa kussakin säkeistössä $(1 ., 2 ., \ldots)$ säkeittäin $(a, b, \ldots)$. Säkeestä toiseen siirrytään vasemmalta oikealle. Toinen pystysuora sarake (L) näyttää, kuinka monta tavua veisaaja veisaa. Sanatäydennysten yms. vuoksi se ei välttämättä ole sama kuin painetussa tekstissä. Tämä tavumäärä ilmenee nuotinnoksesta. Kolmas pystysuora sarake (MS) osoittaa ns. melodisten sävelten lukumäärän. Tämä kohta saattaa joskus olla hieman tulkinnanvarainen. Melodisiksi säveliksi en ole laskenut ns. sävelen toistoja eli ko. virressä kahta tai useampaa samassa iskualassa (mitaltaan) olevia samantasoisia, peräkkäisiä säveliä. Mahdolliset sävelen toistot voidaan päätellä taulukkoa luettaessa.

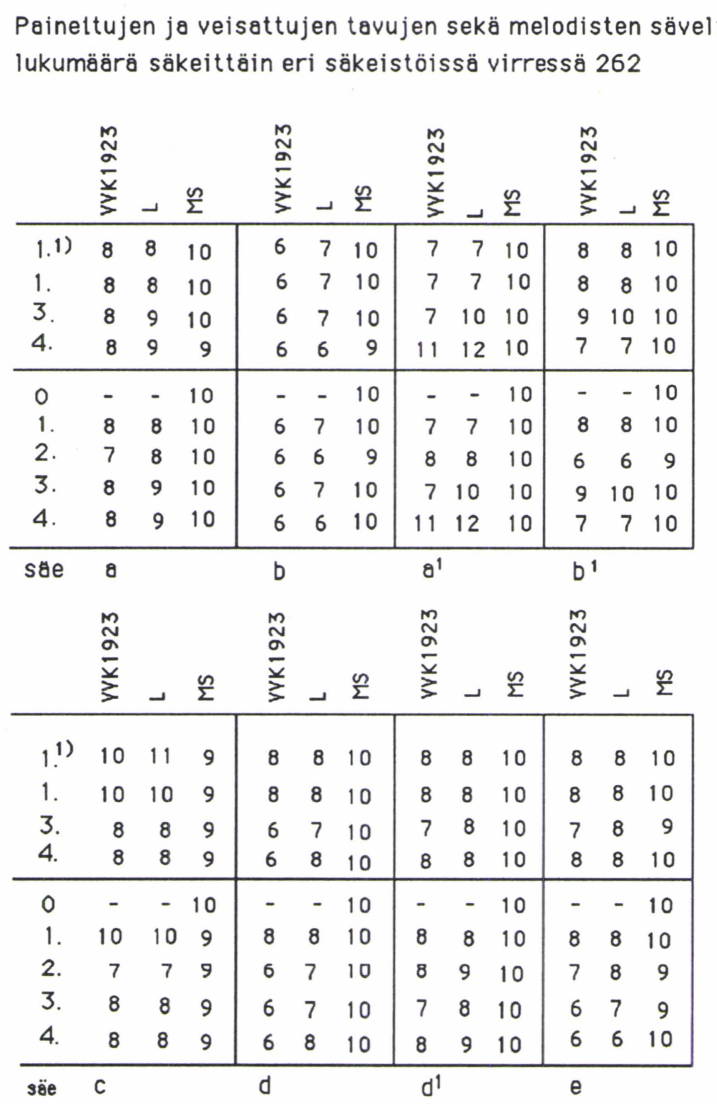

Taulukko 1 
Ohjeita Taulukon 1 lukemiseksi:

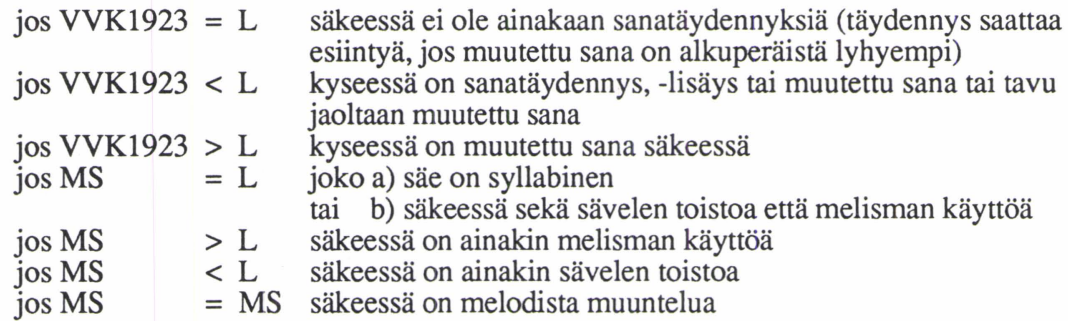

Virsikirjassa, jota Kerttu Hannula käytti minulle veisatessaan (vuoden 1923 painos) virressä 262 on kolmekymmentäseitsemän (37) heittomerkillä katkaistuiksi merkittyä sanaa, esimerkiksi "minull’’". Säkeistöittäin jakauma on 7 (1. säkeistö), 9 (2.), 13 (3.) ja 8 (4.). Vuoden 1986 versiossa hän täydentää näistä kokonaisiksi sanoiksi kuusitoista (16) (1.1) säkeistön kanssa) ja kolmetoista (13) (1. säkeistön kanssa). Vuonna 1986 Hannula ei veisannut toista säkeistöä lainkaan, joten tässä ei tehdä aikavertailua, koska kaikista säkeistöistä ei ole vähintään kahta versiota. Vuonna 1989 hän veisasi kaikki neljä säkeistöä ja täydensi katkaistuista sanoista kahdeksantoista (18), säkeistöittäin 1 (1. säkeistö), 4 (2.), 9 (3.) ja 4 (4.).

\begin{tabular}{|r|cccc|l|}
\hline & 1. säk & 2. säk & 3. säk & 4. säk & \\
\hline VKK 1923 & 7 & 9 & 13 & 8 & $=37$ katkaistua sanaa, joista \\
1986 & $(4)^{1 / 1}$ & - & 9 & 3 & $=(16) 1 / 13$ täydennettyä \\
1989 & 1 & 4 & 9 & 4 & $=18 \quad-\quad$ - \\
\hline
\end{tabular}

\section{Taulukko 2}

Kun katkaistujen ja täydennettyjen sanojen suhde vuonna 1986 oli (16) 13/ 28 ja vuonna 198918 / 37, voidaan karkeasti sanoa, että Hannula täydensi puolet heittomerkillä varustetuista sanoista. Lisäksi virressä on kaksi kohtaa, jotka hän muuttaa virsikirjan tekstistä poikkeavaksi: itseni $\rightarrow$ itsen (1.1) $\left.b^{1}\right)$ ja täält $\rightarrow$ täältä (4. d). En käsittele viimeksi mainittua sanatäydennyksenä, koska sitä ei oltu Hannulan virsikirjassa merkitty heittomerkillä katkaistuksi.

\section{Väitteet}

Olen laatinut joitakin väitteitä sanatäydennysten ja melodian sekä sanojen ja rytmiikan välisestä suhteesta, ja tarkastelen niiden todenperäisyyttä. Väitteiden taustalla ovat aikaisempien nuotinnosten ja virsien opettelun 
tuomat ajatukset siitä, millaisia säännönmukaisuuksia voisi esiintyä, mutta väitteitä laatiessani en ole olettanut, että ne pitäisivät paikkaansa.

Väite 1: $\quad$ Säkeen viimeistä sanaa ei täydennetä mikäli se on katkaistu.

Virsitekstissä (v. 1923) on kaksitoista (12) säkeen viimeistä sanaa merkitty katkaistuiksi. Vuonna 1989 Kerttu Hannula veisasi kaikki säkeistöt, eikä yhdenkään säkeen loppusanaa täydennetty. Vuonna 1986 veisatuissa säkeistöissä tilanne on täysin samanlainen. Eli vuoden 1989 version perusteella väitteen 1 todeksi osoittavat ( $\%$ kaikki kaksitoista (12) tapausta ja epätodeksi (V) ei yhtään (0). \% 12 / $12 \mathrm{~V} 0 / 12$

Väite 2: a) sana täydennetään jos melodia liikkuu eri sävelelle ja b) sanaa ei täydennetä, vaikka melodia liikkuu eri sävelelle (vastakohtia).

Väitteen idea syntyi siitä, että halusin tietää, missä määrin Hannula veisaa sanan täydennettynä syllabisesti, jos siihen on melodisten sävelten puolesta mahdollisuus.

Virrestä etsitään ensin täydennetyt sanat. Väitteen epätodeksi osoittavat kaikki ne tapaukset, joissa sana on täydennetty, vaikka melodiassa ei mennäkään eri sävelelle. Täydennetyt sanat voi nähdä nuotinnoksesta: tavu, jonka kohdalla täydennys sijaitsee, on alleviivattu ("jon-ka"). Väitteen epätodeksi osoittavien tapausten kohdalle laadin selityksen.

(Kohta a) Vuoden 1986 versiossa on kolmestakymmenestäviidestä (35) katkaistusta sanasta täydennetty kuusitoista (16) (huom. säkeistö 1.1) on myös mukana). Niistä neljässä tapauksessa sävelkorkeus säilyy samana (sävelen toisto) eli ne osoittavat väitteen epätodeksi. Yhdessätoista (11) sävelkorkeus muuttuu. \% $11 \mathrm{~V} 4$ kaikissa on kyseessä sävelen toisto (1.1) c; 3., a, $\left.\mathrm{a}^{1} ; 4 . \mathrm{a}\right)$.

Vuoden 1989 versiossa (kaikki säkeistöt) on kolmessakymmenessäseitsemästä (37) katkaistusta sanasta täydennetty kahdeksantoista (18). Neljässä on käytetty sävelen toistoa ja seitsemässä eri sävelkorkeuksia. \%. $7 \mathrm{~V} 4$ kaikki sävelen toistoja (2., a; 3., a, $\mathrm{a}^{1} ; 4$., $\left.\mathrm{d}^{1}\right)$

(Kohta b) Tässä kohdassa lasketaan ensin täydentämättömät tavut (salat'́) ja katsotaan, missä tapauksissa sanaa ei täydennetä, vaikka melodia liikkuu eri sävelelle (kohta b). Yhteenvedossa nämä tapaukset lasketaan osoittamaan vääräksi kohdan a).

Ensin käsittelen vuonna 1986 veisatut säkeistöt. Täydentämättöminä veisattuja sanoja on yhdeksäntoista (19), joista 14 sijaitsee säkeiden lopussa. Ensimmäisessä ( 1., v. 1986 ja -89 versiot) säkeistössä, säkeessä b ${ }^{1}$ on sana, jota Kerttu Hannula ei täydennä, vaikka melodisten sävelten osalta 
siihen olisi mahdollisuus (huom. säkeistö 1.1), vastaava säe osoittaa oikeaksi kohdan a) ). Samoin on 4. säkeistön säkeessä e: "tai-vaan"". Muut täydentämättömät tavut ovat syllabisia, kahdeksasosa- tai neljäsosanuotin mittaisia säveliä eli $2 \mathrm{kpl}$ osoittaa epätodeksi kohdan a).

Vuonna 1989 veisatut säkeistöt. Täydentämättöminä veisattuja sanoja on yhdeksäntoista (19), joista seitsemän sijaitsee muualla kuin säkeiden lopussa. Viidessä on melisma eli sävelmä liikkuu eri sävelille $\left(1 . b^{1}, 2 . b\right.$, 2. $a^{1}, 2 . b^{1)}$ ja 4.e). Loput kaksi täydentämätöntä tavua ovat syllabisia, kuten vuoden 1986 versiossakin. Eli $5 \mathrm{kpl}$ osoittaa epätodeksi kohdan a), joten lopullinen suhde väitteen 2 a) osalta on seuraava: $\% 18 \mathrm{~V} 15$

Väite 3: a) sanaa ei täydennetä, jos melodia liikkuu ylöspäin ja

b) sana täydennetään, jos melodia liikkuu alaspäin (itsenäisiä väitteitä)

Lähtökohtana tässä on suomen kielen luonnollinen "melodia", laskeva sanan loppu. Vaikuttaako puhuttu kieli vanhan virsikirjan veisuutapaan? Käsittelen molemmat väitteet samanaikaisesti.

\begin{tabular}{|c|c|c|c|c|c|}
\hline \multirow[t]{2}{*}{ Vuoden 1986 versio: } & $\%$ & 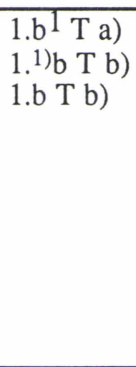 & V & 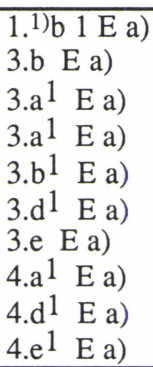 & $\begin{array}{l}\text { ("jonka") } \\
\text { ("päälleni") }\end{array}$ \\
\hline & yht. & $\begin{array}{l}1 \mathrm{kpl} \mathrm{a)} \\
2 \mathrm{kpl} \mathrm{b})\end{array}$ & yht. & $\begin{array}{l}8 \mathrm{kpl} \mathrm{a)} \\
2 \mathrm{kpl} \mathrm{b})\end{array}$ & \\
\hline \multirow[t]{2}{*}{ Vuoden 1989 versio } & $\%$ & $\begin{array}{l}\text { 1.b } \mathrm{T} \text { a) } \\
\left.\text { 1. } \mathrm{b}^{1} \mathrm{~T} \mathrm{~b}\right) \\
2 . \mathrm{b}^{\mathrm{T}} \text { ) } \\
\left.2 \mathrm{a}^{1} \mathrm{~T} \mathrm{a}\right) \\
\left.2 . \mathrm{b}^{1} \mathrm{Ta}\right) \\
\left.2 . \mathrm{d}^{1} \mathrm{~T} \mathrm{~b}\right)\end{array}$ & $\mathrm{V}$ & 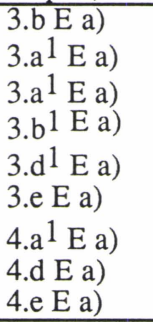 & $\begin{array}{l}\text { ("jonka") } \\
\text { ("päälleni") }\end{array}$ \\
\hline & yht. & $\begin{array}{l}4 \mathrm{kpl} \mathrm{a)} \\
2 \mathrm{kpl} \mathrm{b})\end{array}$ & yht. & $\begin{array}{l}8 \mathrm{kpl} \mathrm{a}) \\
1 \mathrm{kpl} \mathrm{b}) \\
\end{array}$ & \\
\hline Molemmat versiot yhteenlaskettuina: & $\%$ & $\begin{array}{l}5 \mathrm{kpl} \mathrm{a)} \\
4 \mathrm{kpl} \mathrm{b})\end{array}$ & $\mathrm{V}$ & $\begin{array}{l}16 \mathrm{kpl} \mathrm{a)} \\
3 \mathrm{kpl} \mathrm{b})\end{array}$ & \\
\hline
\end{tabular}

Lyhenteet: $\quad$ T a) = osoittaa todeksi kohdan a)

$\mathrm{E}$ a) $=$ osoittaa epätodeksi kohdan a)

Taulukko 3 
Väite 4: $\quad Y k s i$ veisattu tavu ei ole kestoltaan pitempi kuin neljäsosanuotin mittainen.

Mikäli tämä väite pitää paikkaansa, vähätavuisissa säkeissä ilman täydennystä jokin melisma tulisi aika-arvoltaan liian pitkäksi. Tässä on hyvä muistaa, että kyseessä on veisattujen tavujen pituudet, joten esimerkiksi

$\neg=\int$ ja $\int \sqrt{J}=d$. Lasken ensin veisattujen tavujen lukumäärän (Taulukko 1, sarake L) ja tarkastelen sitten tavujen sävelpituuksia.

Vuoden 1986 versiossa veisattuja tavuja on 259, jotka kaikki osoittavat väitteen todeksi. ( $\% 259$ / 259 V 0 / 259).

\section{Tavujen mitoista yleensä:}

Tavujen kestot vaihtelevat tässä versiossa kuudestoistaosanuotin ja pisteellisen neljäsosanuotin välillä seuraavasti: $\$ 12, \quad$ "\$ $7, \$ 63, \quad \AA^{3-} 7$, d 170 eli yht. $259 \mathrm{kpl}$.

Neljäsosanuotin mitta on hallitsevin, $170 \mathrm{kpl}$.

Vuoden 1989 versiossa veisattuja tavuja on 254, jotka kaikki osoittavat väitteen todeksi. ( \% 254 / 254 V 0 / 254)

Tässä versiossa tavujen kestot vaihtelevat kuudestoistaosanuotin ja neljäsosa-

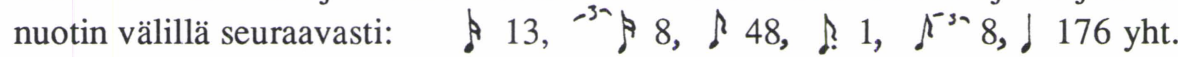
$254 \mathrm{kpl}$. Jälleen eniten on neljäsosanuotin mittaisia tavuja, $176 \mathrm{kpl}$.

Väite 5: Iskualan jälkimmäiseltä kahdeksasosanuotilta ei koskaan ala uusi sana, joka jatkuisi seuraavalle iskualalle.

Yhdessä säkeistössä on viisikymmentäkolme (53) neljäsosanuotin mittaista iskualaa, joten molemmissa versioissa niitä on yhteensä 9 x 53 eli $477 \mathrm{kpl}$. Kaikki osoittavat väitteen todeksi. ( $\% 477 / 477$ V 0 / 477). Väitteiden 1-5 todenperäisyys prosentteina on Taulukon 4. mukainen.

\begin{tabular}{|c|ll|ll|}
\hline & $\%$ & $\%$ & $\mathrm{~V}$ & $\%$ \\
\hline VÄITE 1 & $12 / 12$ & 100 & $0 / 12$ & 0 \\
VÄITE 2 & $18 / 33$ & 54,5 & $15 / 33$ & 45,5 \\
VÄITE 3 a) & $5 / 21$ & 23,8 & $16 / 21$ & 76,2 \\
b) & $4 / 7$ & 57,1 & $3 / 7$ & 42,9 \\
VÄITE 4 & $259 / 259$ & 100 & $0 / 259$ & 0 \\
VÄITE 5 & $477 / 477$ & 100 & $0 / 477$ & 0 \\
\hline
\end{tabular}

Taulukko 4 
Tulosten perusteella Kerttu Hannula ei koskaan täydennä säkeen viimeistä tavua sen ollessa katkaistu. Yhden tavun kesto on korkeintaan neljäsosanuotin mittainen, jollaisia tässä virressä olikin kaikkein eniten: 170 / 259 (v. 1986 versio) ja $176 / 254$ (v. 1989 versio). Toisin sanoen neljäsosanuotin mittaiset sävelet ja melismat ovat juuri tälle virrelle tyypillisiä, mahdollisesti myös koko Hannulan veisuulle. Tässä virressä on paljon melodisia säveliä, jotka Hannula usein veisaa yhden iskualan $(=d)$ mittaisina melismoina ( $\Omega, \sqrt{\jmath}, \Omega$ ). Hän ei pyri säännönmukaisesti käyttämään melodisia säveliä sanatäydennyksiin (VÄITE 2), vaan käyttää sen lisäksi myös sävelen toistoa ( $8 \mathrm{kpl}$ 万 $)$. Hieman todennäköisempää kuitenkin on veisata täydennetty tavu jo olemassa olevalle melodiselle sävelelle kuin olla tekemättä niin tai kuin käyttää sävelen toistoa.

Suomen kielen ns. luonnollisella melodialla ei ole juuri merkitystä sanatäydennysten kannalta (VÄITE 3). Vaikka melodia kulkee ylöspäin $(\nearrow)$, sana täydennetään useinmiten $(76,2 \%)$.

Virren antaman tuloksen perusteella ei ole mahdollista aloittaa uutta sanaa iskualan puolivälistä (VÄITE 5). Ainoa paikka, jossa näin tapahtuu,

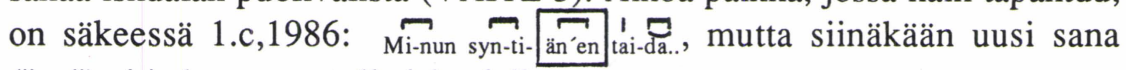
("en") ei jatku seuraavalle iskualalle.

\section{Sääntöjen välinen hierarkia 1}

Joitakin muita selityksiä täydennyksille ja muutoksille virressä 262 väitteiden tulokset huomioiden 2., 3. ja 4. säkeistö, säe d ja säkeen d variantit.

Säe $d$ on seitsemän iskualan mittainen (yksi iskuala on neljäsosanuotin mittainen). Vuoden 1923 virsikirjapainoksen tekstin mukaan tavuja on ko. säkeessä kuusi kappaletta (Taulukko 1). Jos sanatäydennyksiä ei näissä tehtäisi, jouduttaisiin jokin tavu veisaamaan pitempänä kuin neljäsosanuotin mittaisena. Väitteen 4 tuloksen mukaanhan näin ei yleensä tehdä. Jokaisessa säkeistössä (2., 3. ja 4.) täydennykseen on mahdollisuus, ja Kerttu Hannula myös käyttää sen.
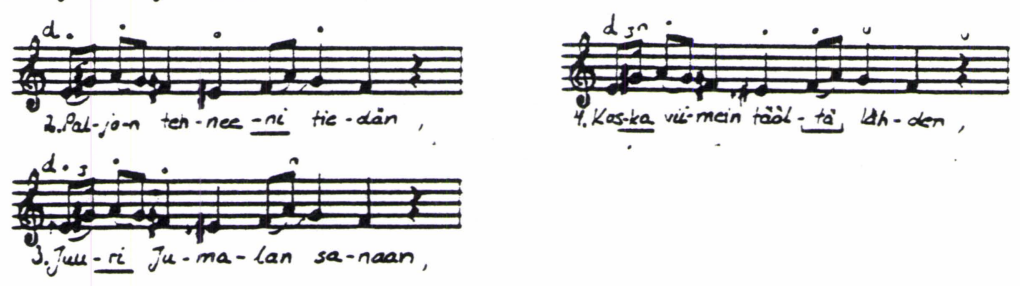

Säkeet $\mathrm{c}, \mathrm{d}$ ja $\mathrm{d}^{1}$ ovat likipitäen samat. Oletan, että kaikissa näissä on pyrkimys siihen, ettei kolmatta ja neljättä iskualaa ylitetä murrelmasanalla. 
Säkeissä c ja d ${ }^{1}$ asia on näin joka säkeistössä mutta säkeessä d vain ensimmäisessä ja neljännessä säkeistössä. Mikäli Hannula ei neljännessä säkeistössä täydentäisi myös sanaa "täält" (huom. ei heittomerkkiä vuoden 1923 painoksessa), tästäkin olisi tavujen vähyyden vuoksi pakko tehdä mur-

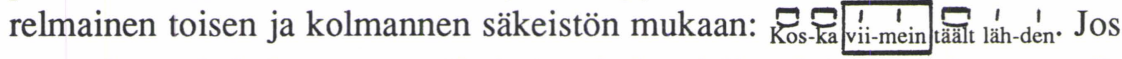
taas toisesta ja kolmannesta säkeistöstä haluttaisiin tehdä murrelmaton, olisi veisattava jokin tavu puolinuotin mittaisena: 7 aal-jon 4 mukaan näin ei tehdä. Toinen mahdollisuus murrelman välttämiseksi

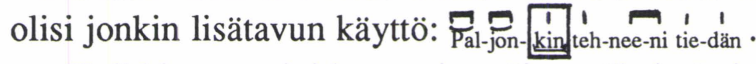

Kaikkien versioiden ensimmäiset säkeistöt ja vertailu toiseen säkeistöön, säe $b^{1}$.

Kuten väitteet 2 ja 3 osoittivat, hypyn tai sävelkulun suunnalla ei ole juuri merkitystä siihen, täydennetäänkö sana vai ei. Tässäkin säkeessä tärkeintä tuntuu olevan murrelmaton toisen ja kolmannen iskualan ylitys.

Tämän vuoksi on mahdollista, että v. 1986 kahdessa eri ensimmäisessä säkeistössä on "syntiseks`"- sana täydennetty (1.1) ja täydentämätön (1.).
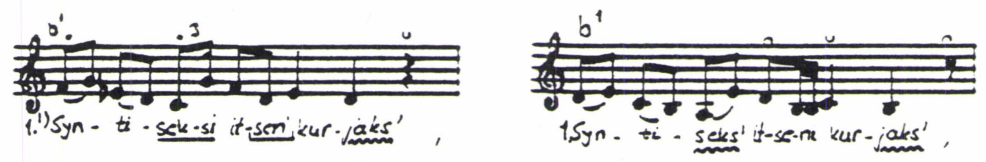

Poikkeus murrelmattomuuteen on toinen säkeistö (v. 1989 versio).

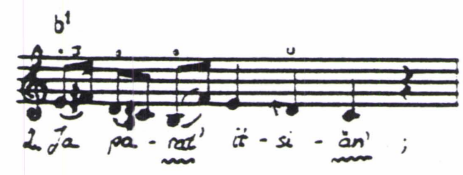

Väitteen 5 mukaanhan sitä ei voi veisata esimerkiksi:[ iskualan jälkimmäiseltä kahdeksasosanuotilta ei koskaan ala vähintään kaksitavuinen sana. Tällä toimenpiteellä säkeen toisen ja kolmannen iskualan ylitys saataisiin murrelmattomaksi.

Molempien versioiden ensimmäiset säkeistöt, säe c
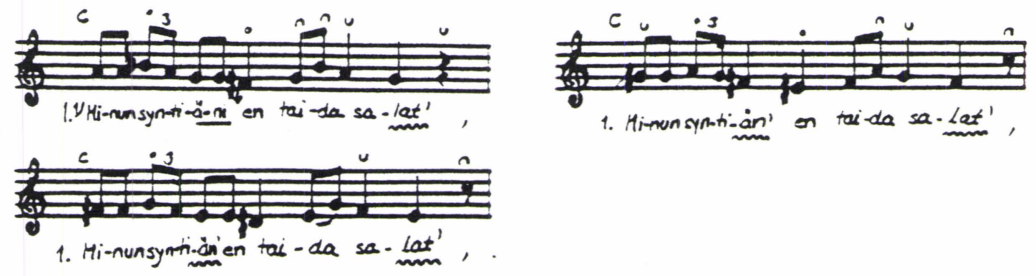

Kaikissa tapauksissa säkeessä on erilainen ratkaisu. Se johtuu vain siitä, että kolmannen ja neljännen iskualan ylitys pyritään pitämään murrelmat- 
tomana. Säkeessä on vuoden 1923 virsikirjapainoksessa paljon tavuja (10 kpl). Sävelen toistonkin täytyy sisältyä mukaan, koska melodisia säveliä on vain yhdeksän (Taulukko 1, sarake MS).

Neljäs säkeistö, säe $\mathrm{d}^{1}$
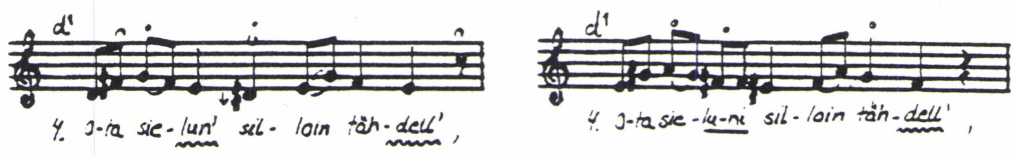

Kuten jo todettiin, tässäkin säkeessä pyritään saamaan kolmannen ja neljännen iskualan ylitys murrelmattomaksi. Näin ollen "sielun'"- sanan täytyy olla ennen tätä rajakohtaa. Säkeessä on kahdeksan tavua (yhdeksän täydennys mukaan lukien), joten ei ole mitään syytä venyttää ko. sanaa kol-

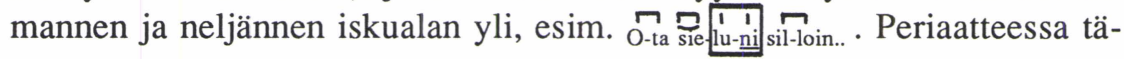
mä kyllä olisi mahdollinen ratkaisu. Tällöin ei kuitenkaan veisaajalle jäisi valinnanvapautta, vaan "sielun`"- sana olisi täydennettävä.

Säkeistö 1.1), säe b ${ }^{1}$

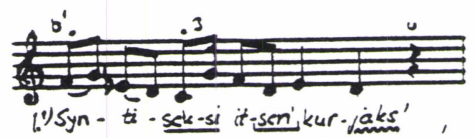

Kyseessä on sanan muutos, tässä tapauksessa sanan lyhennys. Voisiko säkeen veisata esim. Syn-ti-sek-si it-se-ni kur-jaks'? Ainakaan toisen ja kolmannen iskualan välinen murrelmattomuus ei rikkoutuisi.

\section{Sääntöjen välinen hierarkia 2}

Virsi 262 osoittaa, että tärkeintä on pitää yhden tavun mitta korkeintaan neljäsosanuotin mittaisena. Jotta sävelen mitta ei ylittäisi neljäsosanuotin mittaa, voidaan murrelmattomuudesta tinkiä (2. säkeistö, säe d). Toisaalta, jos sanaa täydentämällä tai muuten muuttamalla voidaan sävel pitää korkeintaan neljäsosanuotin mittaisena (2. säkeistö, säe d) ja säe tietyssä kohdassa murrelmattomana (4. säkeistö, säe d) on näin syytä tehdä. 
Sääntöjen välinen hierarkia (ylimpänä tärkein sääntö)

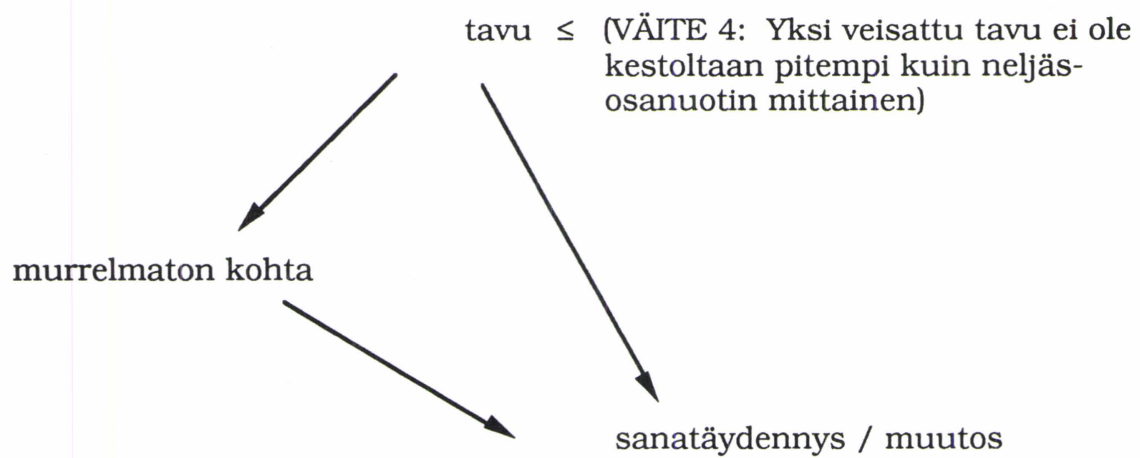

Sääntöjä Vanhan virsikirjan tekstin ja melodian yhdistämiseksi Hannulan mallin mukaisesti edellä esitetyn tarkastelun perusteella

Kun lähdetään laatimaan sääntöjä, miten vanhan virsikirjan tekstin ja melodian voisi oppia yhdistämään ilman, että on kuullut niiden elävää esitystä tai että on kokenut niitä tilanteita, joissa vanhan virsikirjan virsiä on veisattu, on syytä muistaa, että tässä tilanteessa on kyse lähinnä viitteellisistä tiedoista. Näin sen vuoksi, että tein tutkimuksen vain yhdestä virrestä. Tuloksia vahvistaa toisaalta se, että sain hyvin saman suuntaisia tuloksia muista Kerttu Hannulan veisaamista virsistä aikaisemmissa töissäni.

Vanhan virsikirjan tekstissä osa sanoista on heittomerkillä merkitty katkaistuiksi. Toisinaan veisaaja kuitenkin täydentää sanat. Hannula täydensi virren 262 katkaistuista sanoista noin puolet.

Tärkeimpiä periaatteita sanojen täydennyksissä ja yleensä sanojen sijoittelussa melodiaan ovat seuraavat:

- säkeen lopettavaa katkaistua tavua ei koskaan täydennetä

- mikäli melodiassa on paljon melodisia säveliä, on jonkin verran tavallisempaa veisata sanatäydennys jo olemassa oleville sävelille kuin käyttää sävelen kaksinnusta eli toistoa (melodian kulkusuunnalla ei ole merkitystä sanatäydennysten kannalta eli sanan voi täydentää ja veisata sävelet syllabisesti tai olla täydentämättä ja veisata melismalla riippumatta melodian kulkusuunnasta)

- sanatäydennyksen vuoksi sävelmään ei lisätä melodisia säveliä vaan käytetään mieluummin sävelen toistoa

- sävelen toistoa sanatäydennyksiin tai sanojen sijoitteluun yleensä käy- 
tettäessä sävel voi olla kahdeksas- tai kuudestoistaosanuotti

- $\quad$ tärkeää on pitää yhden tavun mitta korkeintaan yhden iskualan eli neljäsosanuotin mittaisena, kirjassa olevan tavuluvun ollessa pienempi kuin melodisten sävelten lukumäärä, voidaan joutua tilanteeseen, jolloin ilman sanatäydennystä tai jonkinlaista muunlaista lisäystä em. tavun keston yläraja ylittyy; kaksi perättäistä kahdeksasosanuottia voidaan veisata yhdellä tavulla melismana, jolloin tavun mitta on edelleen sallittu neljäsosanuotin mitta

- uutta, vähintään kaksitavuista sanaa ei saa aloittaa iskualan puolivälistä. Yksitavuisen sanan kohdalla näin voi tehdä

- kolmitavuisen sanan ollessa melodisesti asteittain alaspäin kulkevan säkeen viimeisenä sanana voidaan valtamelodiassa mahdollisesti esiintyvä melisma 'suoristaa' ja veisata näin pelkkä asteittainen alaspäinen kulku

Havaitsin myös seuraavien tekijöiden olevan tärkeitä yhdistettäessä melodiaa ja tekstiä Hannulan mukaan:

- $\quad$ eri versioissa sana voidaan täydentää tai olla täydentämättä, periaatteena tällöin on kuitenkin se, että kyseinen sana tai tavu veisataan molemmilla kerroilla samalla iskualalla; ensimmäisessä on tällöin kyse sävelen toistosta ja jälkimmäisessä syllabisesta veisuusta, jossa ei ole sävelen toistoa,

- virren melodiassa melismat saattavat olla tietyissä paikoissa niin vakiintuneita, että sanatäydennykset tai liikatavut veisataan mieluummin kuudestoistaosanuottien mittaisina sävelen toistoina kuin muutetaan kyseiset melismat syllabisiksi,

- $\quad$ eri säkeistöjä tai melodisesti samanlaisia säkeitä verrattaessa huomataan, että melodiassa saattaa olla kohtia, joita ei ylitetä murrelmasanalla; sen vuoksi voidaan esimerkiksi joutua käyttämään sävelen toistoa tai sanan muutosta sanojen sijoittelussa melodiaan niin, ettei havaittua murrelmatonta kohtaa rikottaisi,

- joissakin säkeissä taas veisaajalla on eri säkeistöissä hyvin erilaisia ratkaisuja; näitä voi käyttää ratkaisumalleina vastaavanlaisissa säkeissä Ilman kuulohavaintoja vanhan virsikirjan virsien tekstiä ja melodiaa on hyvin vaikea yhdistää tyylinmukaisesti. Edellä olevilla sääntöjä noudattamalla voidaan vain välttää karkeimmat tyylivirheet. On kuitenkin syytä muistaa, että edellä esitetyt asiat pätevät näillä tiedoin vain Kerttu Hannulan veisuuseen. 


\section{Umpi- ja avotavujen veisaaminen}

Tarkastelin lopputyössäni (Järvinen 1990) myös vokaalien mittoja sekä konsonanttien veisuutapaa Kerttu Hannulan veisatessa virren 262. Tutkin myös erilaisiin äänteisiin päättyvien tavujen veisuutapaa ja niiden mahdollista vaikutusta veisuun sisäiseen rytmiin. Tavua kutsutaan umpitavuksi silloin, kun se päättyy konsonanttiin ja vastaavasti avotavuksi sen päättyessä vokaaliin.

Kansanlaululle on yleensä tyypillistä se, että teksti "vääristyy", esimerkiksi normaalisti lyhyenä lausutusta vokaalista tuleekin pitkä eikä laulussa ole pyrkimystäkään normaalilausumisen mukaiseen ääntämiseen. Usein sana saattaa muuttua ikään kuin erimerkityksiseksi: elämän -> "elämään". Seuraavassa esitän joitakin tuloksia tästä taulukoiden avulla tehdystä tarkastelusta.

Soinnittomaan konsonanttiin päättyvien tavujen osalta niihin kuuluva vokaali oli veisattu aina pitkänä, jolloin tapahtui eniten ns. vääristymiä puheääntämiseen nähden. Toisinaan kun tämä konsonantti oli soinnillinen, sen Kerttu Hannula veisasi selvästi melisman jälkimmäiselle sävelelle ikään kuin omana tavunaan. Nämä tapaukset olivat selvä vähemmistö mutta mielestäni selvästi eräs Hannulan veisuulle ominainen piirre. Loppukonsonantti saattoi pitkänä veisatun vokaalin jälkeen siirtyä selvästi myös neljäsosanuotin mittaisen iskualan viimeiselle neljännekselle. Heränneisiin yhdistettävä säkeen viimeisen tavun veisaaminen lyhyenä eli "töksäytys" ei ole Kerttu Hannulalle tyypillistä, koska hän saattoi jatkaa loppusävelten sointia pidentämällä viimeistä soinnillista konsonanttia. Lisäksi kyseisissä kohdissa ei ollut kuultavissa painotuksia. Voi kyllä olla, että virren 262 kaikkien säkeiden päättyminen kahteen asteittain alaspäin kulkevaan säveleen pehmensi lopukkeet niin, ettei "töksähdyksiä" esiintynyt. Kaksoisvokaalien veisaamisessa vokaalit a, e, o, ä ja ö veisataan pidempinä kuin vokaalit i, u ja y.

Virren 262 perusteella hienovarainen rytminkäsittely koskee lähinnä syllabista veisuuta ja lyhyillä avotavuilla veisattuja säveliä, koska melismoissa, joilla Kerttu Hannula veisasi jopa keskimäärin joka kolmannen tavun, valtarytminä oli tasainen kahdeksasosanuottipari. Tavujen päätteillä on myös merkitystä rytmivariaatioihin. Vokaalipäätteisiset melismat Hannula saattoi veisata kahdeksasosanuottiparina tai esimerkiksi triolina, kun taas umpitavuissa valtarytminä oli pelkkä kahdeksasosanuottipari. 


\section{Muuntelu}

Muuntelun tutkimuksen tein myös taulukoiden avulla. Vertasin eri säkeistöjen vastaavia iskualoja keskenään ja etsin syitä sekä rytmisten ja melodisten muuntelujen esiintymiselle että esiintymättömyydelle. Syitä etsin lähinnä tekstin lausumisesta ottaen huomioon samalla mahdollisuuden, että teksti ei vaikuta kyseiseen asiaan.

Rytmisesti tämä virsi koostuu selvästi neljäsosa- ja kahdeksasosanuoteista. Kahdeksasosanuottipareista ja niiden varianteista $69,4 \%$ on veisattu melismoina. Erkki Ala-Könni kirjoittaa:

Eräs erittäin huomattava tuntomerkki, joka erottaa kansanomaiset koraalitoisinnot niiden sävelellisistä alkujuurista, on melismarikkaus. Melisma, kansanomaiselta nimeltä niekku, tarkoittaa sitä kaksi- tai useampisävelistä kuviota, joka lauletaan samalla tavulla. Tämä ilmiö on myös kansanomaiselle soitinmusiikille ominainen. (Ala-Könni 1953, 27).

Erkki Ala-Könni on saanut Lapuanseudun herännäisveisuun melismallisuutta tutkiessaan tuloksen, että keskimäärin joka viidettä $(19,4 \%)$ tavua vastaa melisma (Ibid., 28). Vastaavanlainen vertailu Kerttu Hannulan veisaaman virren 262 osalta antaa tuloksen $28,3 \%$. Kun sävelen toistoja ei oteta huomioon (18 kpl), kahdeksasosanuottipareista ja sen varianteista neljäkymmentä-kuusi (46) on veisattu syllabisesti.

Kuten vanhan virsikirjan teksteissä yleensäkin, virressä 262 teksti ei ole mitaltaan ja tavuluvultaan säännönmukainen. Kuten Taulukko 1 osoittaa, virressä 262 on eri säkeistöissä eri määrä tavuja. Suurin virsikirjatekstin mukainen vaihtelu on säkeessä c (7- 11 tavua), jotka Hannula veisaa täydennysten kanssa 7-12 tavuna.Tämä on asia, joka on veisaajasta riippumaton muiden kuin täydennysten osalta. Nämä ns. liikatavut aiheuttavat siten ainakin rytmisiä eroja eri säkeistöjen välille.

Virren melodia kulkee suurelta osin kahdeksasosanuotteina. Taulukosta näkee, että melodisia säveliä on säkeessä usein enemmän kuin tavuja, joten tälle virrelle niekut ovat erittäin tyypillisiä, kuten jo todettiin. On siten hyvin todennäköistä, että rytmisiä vaihteluja esiintyi näinkin paljon. Se seikka, että mukana on myös muuttumattomia kohtia, osoittaa sen, että mistään sattumanvaraisuudesta ei ole kyse.

Lähtökohtana Hannulan veisuutyylin määrittelyssä rytmisen muuntelun osalta on periaate, joka havaittiin tarkasteltaessa sanatäydennyksiä sekä tekstin ja melodian yhdistämistä: yhden tavun pituus ei ole pitempi kuin neljäsosanuotti.

Virren melodia tuntuu Hannulalla olevan hyvin vakiintunut. Eri vuosien melodiat eivät melodisesti poikkea toisistaan neljättä säkeistöä lukuun- 
ottamatta. Säkeen kaksi viimeistä iskualaa ovat muuttumattomia. Melodialle ovat tyypillisiä rytmisesti hieman varioivat kahdeksasosanuoteista muodostuvat kulut, jotka useimmiten veisataan melismoina. Melismojen esiintymisestä Hannulalla oli sellainen muistikuva, että vanhemmat miehet käyttivät veisatessaan enemmän niekkuja. Hän arveli sen olevan vielä vanhempaa veisuun tyyliä. Tästä tulee väistämättä mieleen kalevalainen laulu kontra riimillinen kansanlaulu: Onko usein hyvin niekutteleva kalevalainen laulu osoitus siitä, että juuri niekut kuuluvat vanhimpaan kansanlaulutyyliin?

Ainoat täysin syllabiset säkeet virressä 262 ovat neljännen säkeistön säe $\mathrm{a}^{1}$ ja ensimmäisen säkeistön säe $\mathrm{c}$ molempien vuosien versioissa. Näissä virsirunon tavumäärä ylittää melodisten sävelten lukumäärän (Taulukko 1), joten sanojen sovittamiseen on tarvittu sävelen toistoa. Tavuja ei soviteta melodiaan lisäämällä melodisia säveliä (melodinen muuntelu) vaan toistamalla säveltä tarvittaessa (rytminen muuntelu). Kaikki tässä virressä esiintyvä melodinen muuntelu onkin valtamelodiaan nähden säveliä vähentävää tai pelkästään rytmisen muutoksen sisältävää (säe c).

Selvä rytminen muuntelu on tyypillistä Kerttu Hannulan veisuulle. Toisinaan se johtuu selvästi pyrkimyksestä sanojen puherytmin mukaiseen lausumiseen. Toisinaan taas Hannula pyrki saamaan tietyt kohdat säkeessä murrelmattomiksi. Tällöin sanojen sijoittelu sai aikaan rytmistä muuntelua, jotta murrelmakohtaa ei syntyisi. Säkeen kahdella viimeisellä iskualalla ei koskaan esiintynyt minkäänlaista muuntelua. Melodiaa Hannula ei koskaan muuntele virren 262 perusteella itsenäisesti, vaan siihen sisältyy aina rytminen muunnos. Hän ei koskaan lisännyt uusia säveliä melodiaan, vaan esiintyvä melodinen muuntelu oli aina valtamelodiaan nähden säveliä vähentävää tai pelkästään rytmisen muunnoksen sisältävää pidemmässä kuin yhden iskualan mittaisessa jaksossa.

Vaikutti toisaalta siltä, että kaikki epätasaisuus pulssissa ei johtunut tekstin mukanaolosta. Joissakin paikoissa melodiakulku ja sen rytmi saattoi olla niin vakiintunut, että tekstin luonnollinen rytmikään ei pystynyt rikkomaan pulssia. Toisaalta teksti ei myöskään vaikuta rytminkäsittelyyn niissä tapauksissa, jolloin Kerttu Hannula veisaa säkeen toiseksi viimeisen neljäsosanuotin mittaisen sävelen hieman mainittua nuottiarvoa lyhyempänä. Melodiassa tietyissä kohdissa sijaitsevien melismojen pysyvyyden vahvuudesta tekstiin nähden kertoo myös se, että joskus säkeiden alussa ensimmäisestä iskualasta siirrytään seuraavaan murrelmalla, vaikka melodistenkaan sävelten osalta niin ei olisi välttämätöntä tehdä. 


\section{Teoria ja käytäntö}

Vaikka osaisi yhdistää vanhan virsikirjan melodian ja tekstin täysin tyylinmukaisesti, ei ole vielä läheskään kyse veisuun koko totuudesta, siitä, mikä saa veisuun todella kuulostamaan tyylinmukaiselta veisuulta. Kuten tulokset osoittivat, rytmin hienojakoinen käsittely ja joiltakin osin sen selvä yhteys tekstiin, puhumattakaan piirteistä, jotka jätin tällä kertaa esittelemättä ja käsittelemättä, ovat mielestäni ainakin yhtä tärkeitä ehtoja, tekijöitä, jotka on tiedettävä ja osattava, jotta vanhan virsikirjan virsien veisuu sujuisi. Veisuun kuunteleminen on jossain oppimisen vaiheessa hyvin tärkeä asia. Niinhän virret on lähes aina opittu.

Muusikkona olen huomannut tärkeäksi asiaksi kansanmusiikin kuulonvaraisessa oppimisessa ja muistamisessa sen, että musiikin tutkimuksessa kiinnitetään huomiota myös erittäin pieniin yksityiskohtiin. Yksityiskohtaisessa tarkastelussa herkistytään erottamaan pieniä vivahteita niin, että musiikin esitystyyliin liittyviä tekijöitä sekä niiden laatua ja määrää on mahdollista analysoiden havainnoida jopa yhden esityskerran perusteella.

\section{Liite}

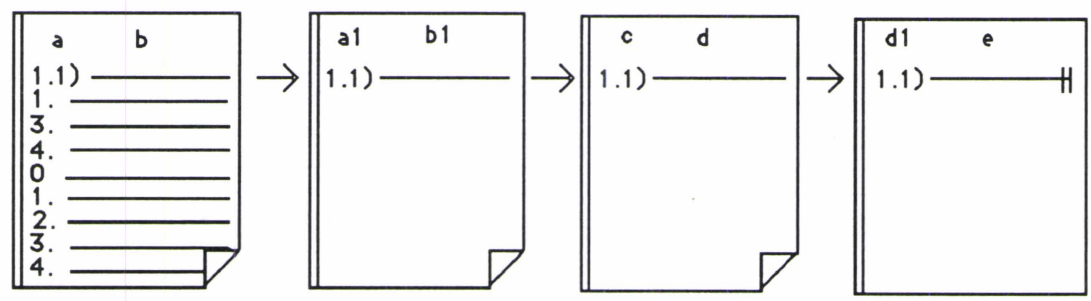

Nuotinnoksen lukeminen: Säkeistöjä vastaavat säkeet ovat alekkain, joten yksi säkeistö on kirjoitettu neljälle sivulle. 


\section{LIITE}

Vanhan virsikirjan virsi 262, Kerttu Hannula (s. 1914)

1.1), 1., 3. ja 4. 12.8.1986; 0-4. 25.3.1989

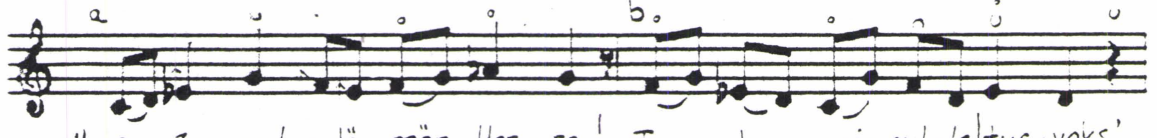

1." 0 jee-su| e-|ä-män Her-ra! Tu - le mi-nub-le tur-vaks',
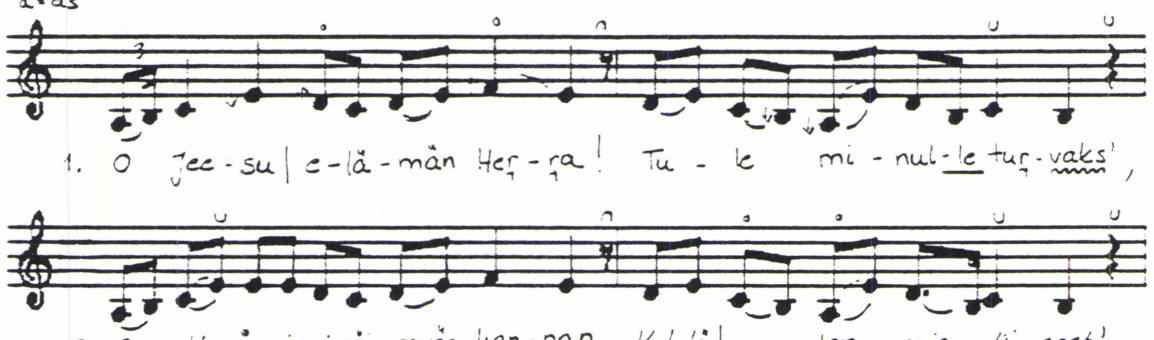

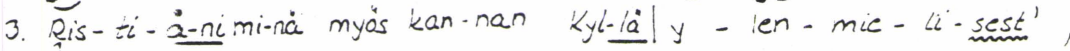
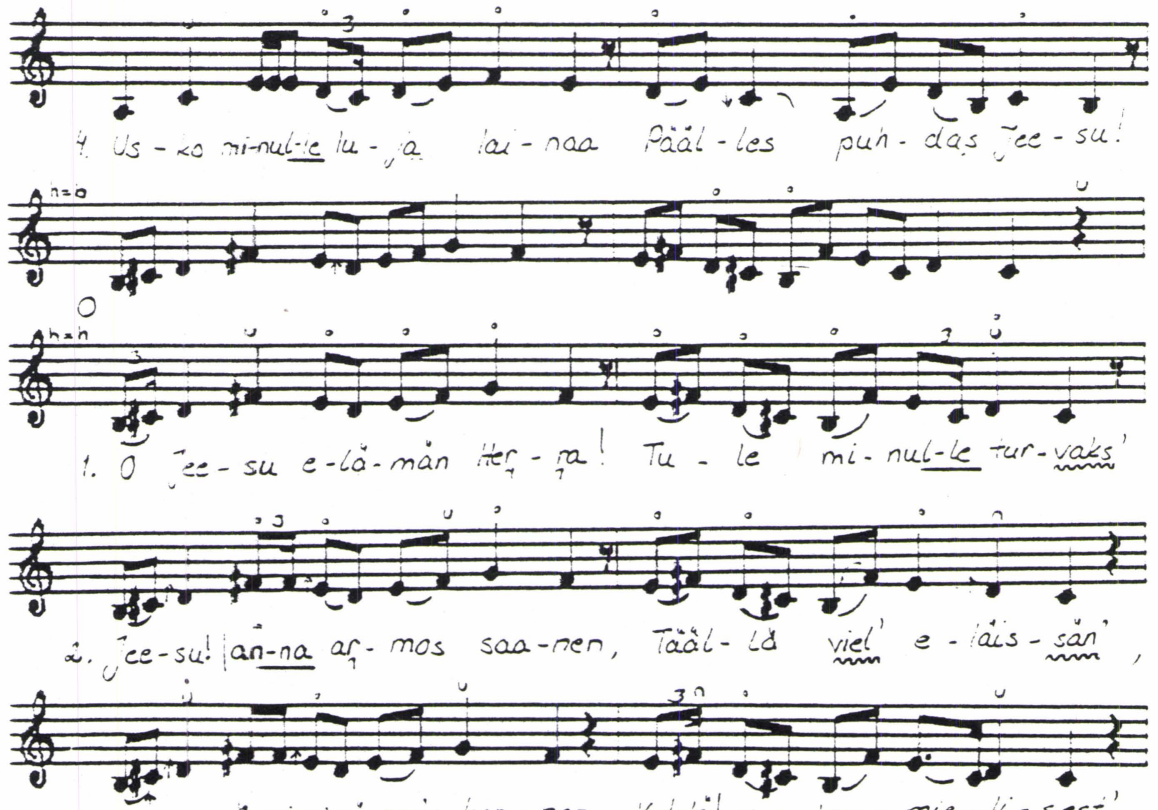

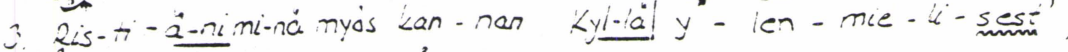

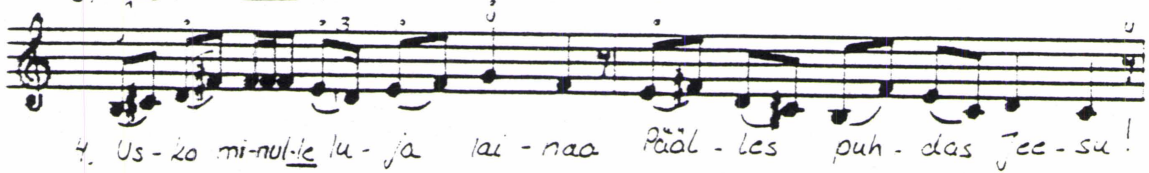



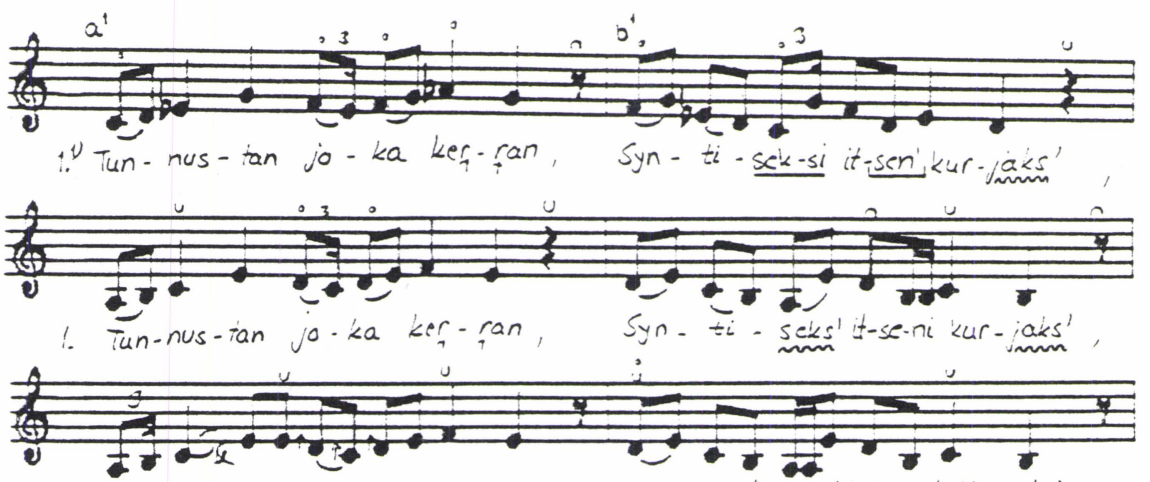

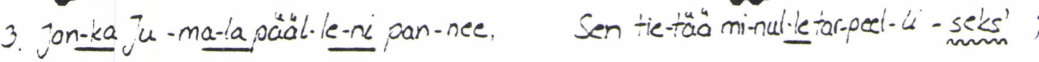
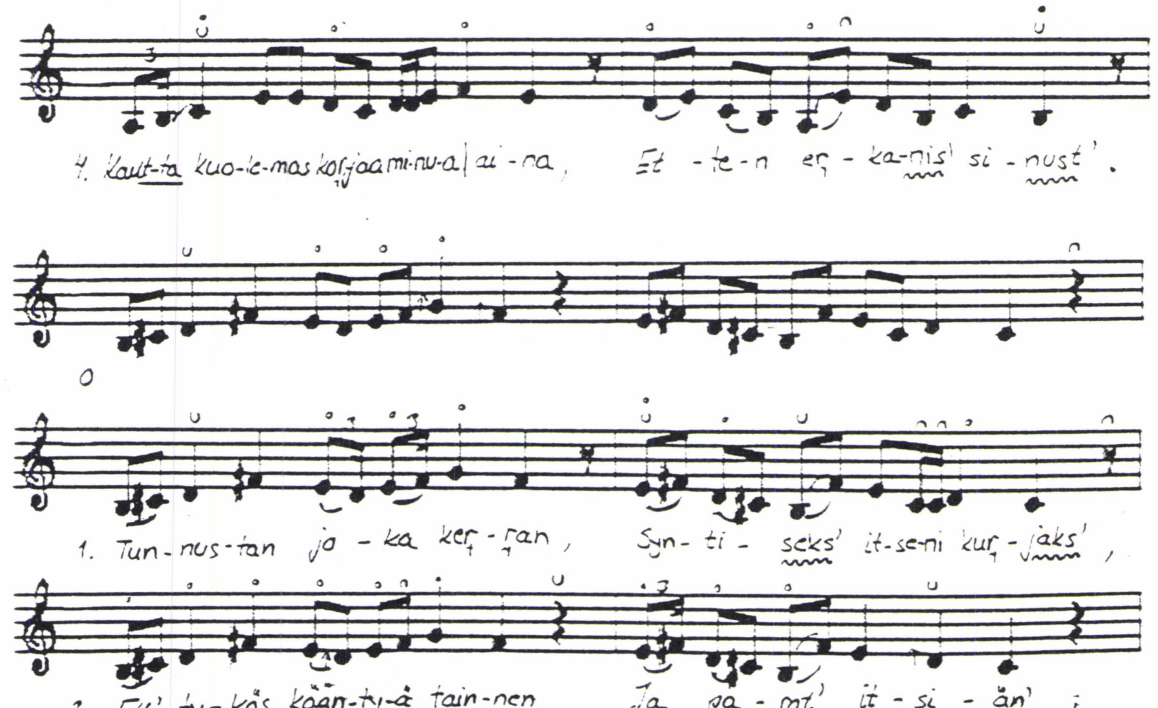

2. Et' ty-kös kään-ty-á tain-nen, ja pa-rat' it-si-ăn' i

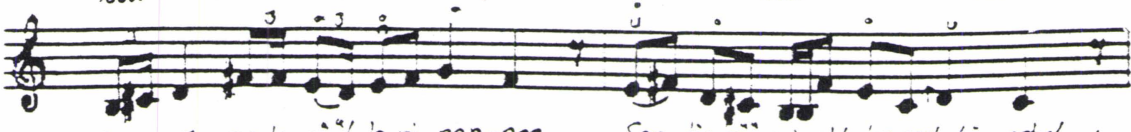

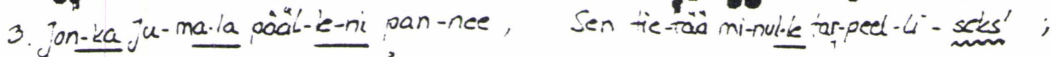

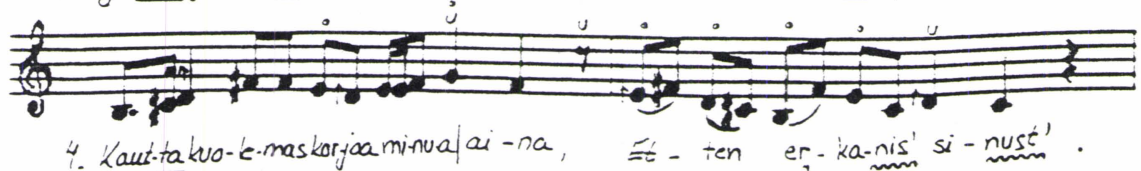



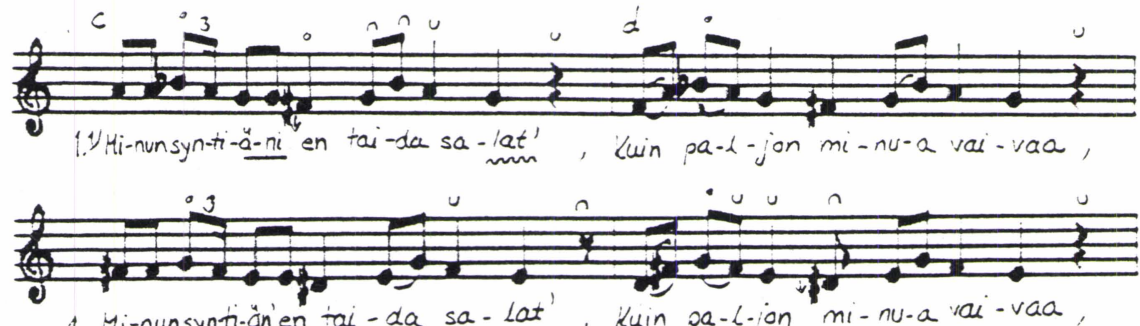

1. Mi-nunsynti-ăn'en tal-da sa-Lat', Kuin pa-l-jon mi-nu-a vai-vaa,

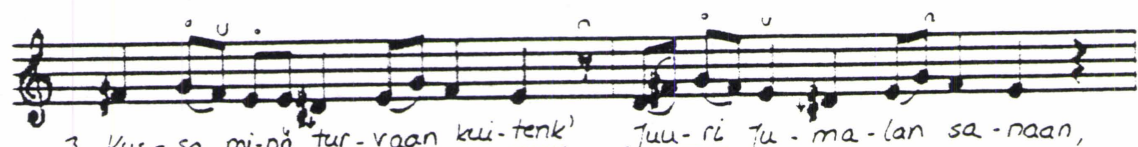

3. Kus-sa mi-ná 'tur-vaan kui-tenk' juu-ri ju-ma-lan sa-naan,

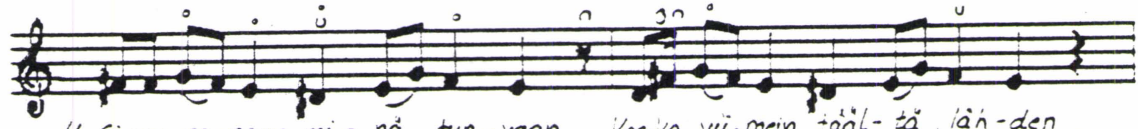

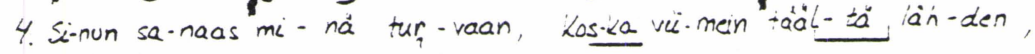
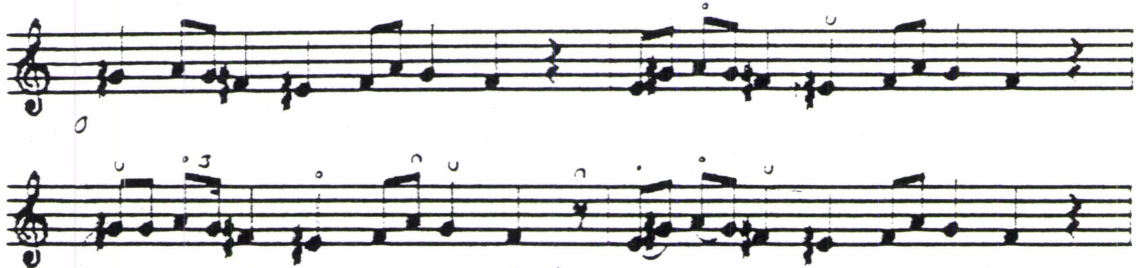

1. Mi-nunsyr-ti-än' en tai-da sa-Lat', Kuin pal-jon mi-nu-a vai-vaa

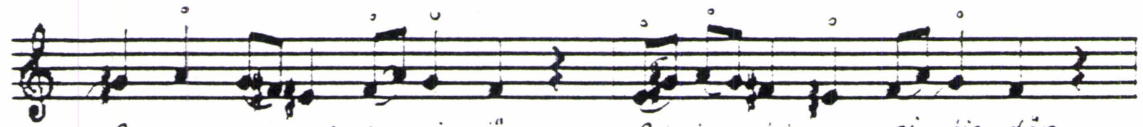

2. Banuut-ta kai-ken i-jän Pab-jo-n ten-nee-ni tic-dän,

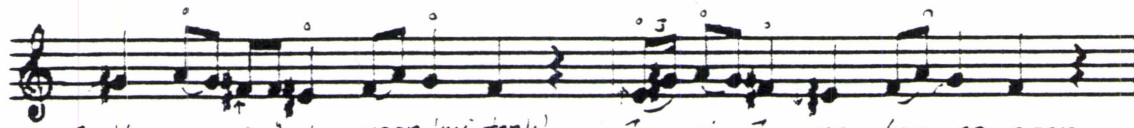

3. 'Lus-sa mi-nà tur-vaan 'kui-tenk' Julu-ri ju-ma-lan sa-naan,

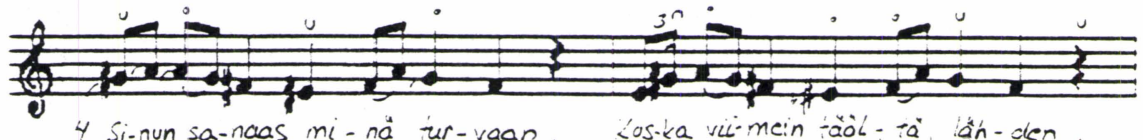

4. Si-nun sa-naas mi-na tur-vaan, cos-ka vil-mein täó- ià lán-den 

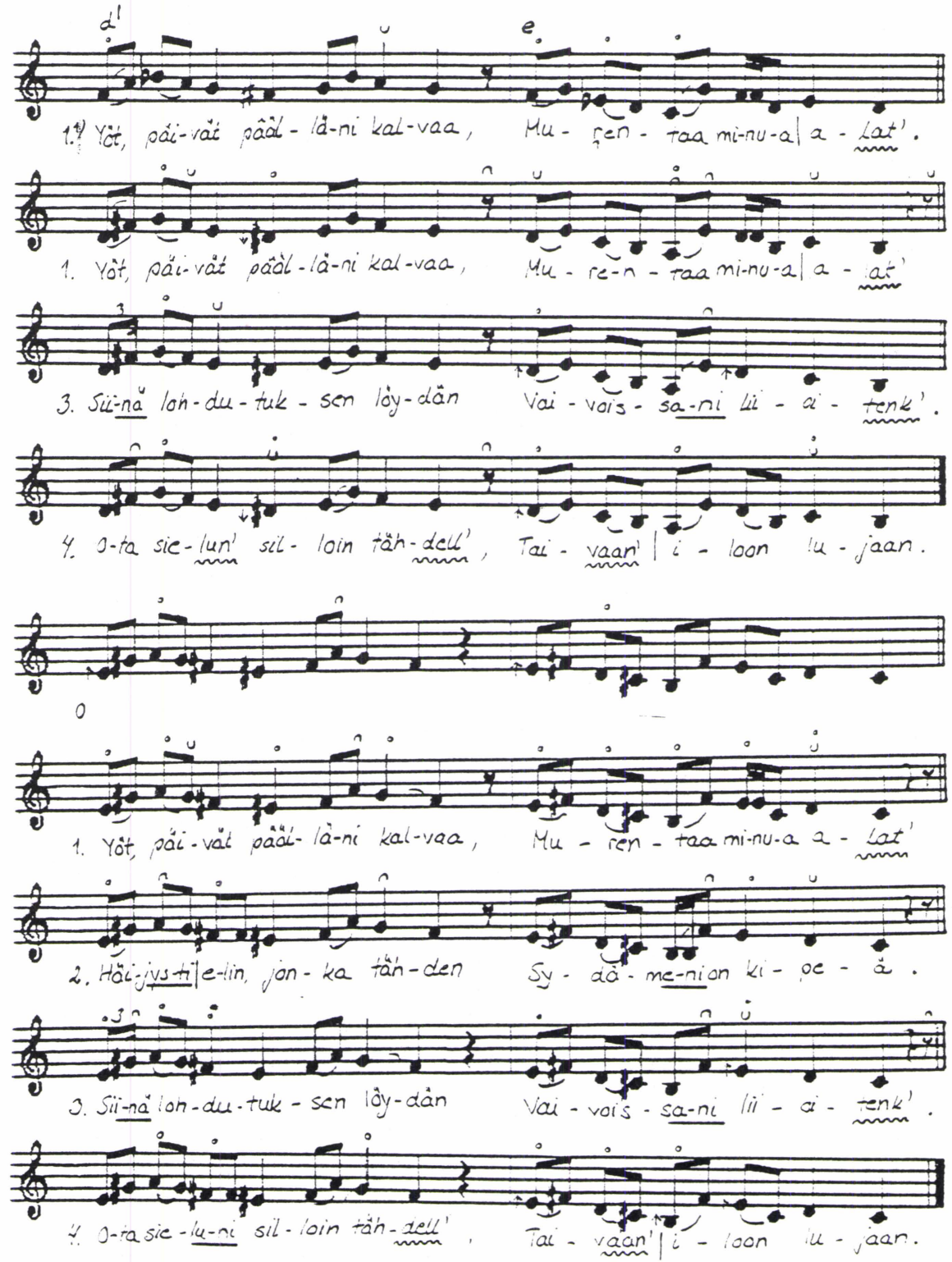


\section{Lähteet}

Ala-Könni, Erkki

1953 "Melismat eli niekut Lapuanseudun herännäisveisuussa", Kalevalaseuran vuosikirja 33.

1974 "Nurmon herännäisveisuu", Suomen kansanmusiikki.

Tutkielmia neljältä vuosikymmeneltä. (Kansanmusiikki-instituutin julkaisuja). 20. Kaustinen 1986.

Boswell, George W.

1978 "Pitch: Musical And Verbal in Folksong." Yearbook of The Intenational Folk Music Council, vol. 9.

Järvinen, Sinikka

1988 Vanhan virren sana ja sävel puntarissa - kumpi painaa enemmän? Sibelius-Akatemia, musiikkianalyysityö 29.4.1988. (moniste).

1990 Veisuun ehdot Ylivieskalaisen herännäisveisaajan, Kerttu Hannulan vanhan virsikirjan veisuutyyli. Tutkielma musiikin kandidaatin tutkintoa varten, Sibelius-Akatemia, Kansanmusiikin koulutusohjelma. (moniste).

Kurvinen, Onni

1941 Vanha virsikirja. Vuoden 1701 virsikirjan synty ja sisällys. Rauma.

Louhivuori, Jukka

1988 Veisuun vaihtoehdot. Musiikillinen distribuutio ja kognitiiviset toiminnot. Jyväskylä.

Robins, R.H. - McLeod, Norma

1956 "Five Yurok Songs: A Musical And Textual Analysis", Bulletin of The School of Oriental And African Studies 18(3).

Suojanen, Päivikki

1984 Finnish Folk Hymn Singing, Study in Music Anthropology. Tampere.

Voipio, Aarni

1948 Virsien Runousoppi. Helsinki.

1955 Virsien pyhä runous. Porvoo. 